\title{
Effects of Diuron Residues on the Growth \\ Performance of Jute (Corchorus. olitorius) Plant and Its Rhizosphere Soil Microbial Population
}

\author{
Solomon A. Adejoro (Corresponding author)
}

Department of Crop, soil and Pest Management, Federal University of Technology, Akure, P.M.B 704, Nigeria, E-mail: solomonajoro@gmail.com, Tel: +234-8068866205

Ajoke C. Adegaye

Department of Crop, soil and Pest Management, Federal University of Technology, Akure, P.M.B 704, Nigeria, E-mail: acaadegaye @ futa.edu.ng, Tel: +234-8164895824

Rex D. Aladesanwa

Department of Crop, soil and Pest Management, Federal University of Technology, Akure, P.M.B 704, Nigeria, E-mail: alarex2003@yahoo.com, Tel: +234-9038680487

Received: February 28, 2019 Accepted: March 31, 2019

doi:10.5296/jbls.v10i2.14613 URL: https://doi.org/10.5296/jbls.v10i2.14613

\begin{abstract}
Soil applied herbicides may persist to adversely affect rotational crops as well as perturb soil microbiological functions. This experiment therefore aimed at determining the effects of soil residual activity of diuron (3,4-dichlorophenyl)-N,N-dimethylurea) on Corchorus olitorius plants and on soil microbial population. Diuron herbicide was applied to potted soils at varying times of 12, 9, 6, 3 and zero weeks before planting Corchorus olitorius. Seed germination, seedling mortality, plant growth as well as soil microbial populations were determined. Results indicated that diuron, regardless of time of application significantly reduced growth parameters of $C$. olitorius plants few days after emergence, and this was followed by $100 \%$ die-back in the herbicide treated pots. Results further showed a reduction in soil microbial population with diuron application, and the reduction was inversely related to time of diuron application before sowing $C$. olitorius. Sensitive vegetables such as $C$. olitorius should not be sown to succeed a short season crop in which diuron had been applied to control weeds at the usual recommended rate of $3.0 \mathrm{~kg}$ a.i/ha. Allowance of a fallow period following the first crop might also help the soil microbial community to recover from diuron toxicity.
\end{abstract}

Keywords: Diuron, microbial population, residual activity, Corchorus olitorius 


\section{Introduction}

Nutrient cycling in soils involves biochemical reactions most of which are mediated by soil microorganisms. However, the use of herbicides can cause toxic effects that may adversely affect these soil organisms (Vieira, 1999; Welp and Brummer, 1999). Persistent herbicides are those herbicides that may not be easily degraded by microorganisms, and as such, they are likely to affect the soil microbial community. The soil activity of diuron, a moderately persistent herbicide has been well reported under field conditions and has been found to have a half-life of 90 days (Heydrich and Fernández, 1984). Diuron is widely used to control weeds and mosses in non-crop areas (Tomlin, 2000). It is also generally applied for selective control of germinating grass and broad-leaved weeds in many crops, including fruit trees, vines, cereals and sugar cane (Tomlin, 2000). Diuron applied pre-emergent to weeds allows seeds to germinate normally, but causes them to lose their green color, after which they soon die of starvation (Ferrell et al., 2004). The most commonly grown cereal crops in southwestern Nigeria is maize, in which diuron may be used pre-emergence to control weeds. Vegetables may be sown to succeed maize in rotation to "catch" remaining moisture under rainfed multiple cropping in this region (Aladesanwa and Adejoro, 2009), but apart from the fact that the fate of diuron residues in soils suggests a threat to sensitive rotational crops because the two metabolites of diuron; $\mathrm{N}$ - (3,4-dichlorophenyl) -N-methylurea and $\mathrm{N}-3$, 4-dichlorophenylurea, present a three times higher toxicity than that of diuron (Bauer, 1998), the herbicide is also able to disrupt the complex ecological community of soil microorganisms, including algae and fungi. It reduced algae populations by 99 percent in the top layer of the soil (Pipe and Cullimore, 1980; 1984). Diuron also reduces the ability of certain algae (cyanobacteria) to fix nitrogen (Gadkari, 1988). The herbicide greatly increased incidence of root rot by increasing the susceptibility of plants to the disease (Guo and Ko, 1996).

The time (90 days) it takes diuron to disintegrate into its highly toxic metabolites coincides with the maturation time of most of the maize varieties grown in southwestern Nigeria, after which a sensitive vegetable crop may be sown to succeed maize in rotation. It is therefore, imperative to confirm previous findings on diuron toxicity to crops and soil microorganisms in a tropical soil. The present study therefore aims at investigating the effects of diuron residues in the soil on the growth of $C$. olitorius as well as on soil microbial population.

\section{Materials and Methods}

\subsection{Chemicals}

All the solvents and other chemicals used were analytical grade and obtained from Pascal Chemical Company Ltd. (Akure, Nigeria). The diuron herbicide used was obtained from local agro dealers in Akure, while the seed of $C$. olitorius (oniyaya variety) was procured from the International Institute of Tropical Agriculture (IITA), Ibadan Nigeria.

\subsection{Soil Sample}

Soil was taken from the Crop Type Museum in the Experiment Station of the Department of Crop, Soil and Pest management, Federal University of Technology, Akure, Nigeria $\left(7^{0} 16^{`} \mathrm{~N}\right.$, 
$\left.5^{0} 12^{`} \mathrm{E}\right)$. Soil samples were collected from a depth of $0-15 \mathrm{~cm}$ in an area with low level of organic matter based on visual observation of the colour. The samples were brought to the laboratory in sealed polyethylene bags. The physicochemical properties of the soil showed $32.3 \%$ clay, $47.7 \%$ silt, $20 \%$ sand, $0.78 \%$ organic carbon, $1.1 \mathrm{~g} / \mathrm{kg}$ total nitrogen, $8.5 \mathrm{mg} / \mathrm{kg}$ available phosphorus and $0.50 \mathrm{Cmol} / \mathrm{kg}$ available potassium. The $\mathrm{pH}$ of the soil was found to be $5.7\left(1: 2 \mathrm{H}_{2} \mathrm{O}\right)$.

\subsection{Treatment Application and Experiment Layout}

A pot experiment, laid out in completely randomized design was carried out in the screen house of the department of Crop, Soil and Pest Management of the Federal University of Technology Akure, south western part of Nigeria. Treatments imposed were application of diuron at the usual recommended rate of $3.0 \mathrm{~kg}$ a.i/ha to the potted soils at varying times of 0 , 3, 6, 9, 12 weeks before sowing (WBS) C. olitorius seeds. Treatments also included a control where no herbicide was applied. Each treatment was replicated four times. Prior to herbicide application, the topsoil was filled into pots (4 liters each) and the herbicide sprayed directly on the potted soil. Spraying began with the set of pots that received diuron treatment at 12 WBS, and continued at three weeks interval until the $12^{\text {th }}$ week, which represented 0 WBS. All potted soils were seeded with $C$. olitorius at the same time regardless of the time of treatment application. Seeds were sown at 10 seeds per pot and germination rate was monitored from the fifth day after sowing when germination was noticed.

The herbicide used was a Dry flowable (80DF) formulation of diuron and was applied with a knapsack sprayer fitted with Polijet nozzles calibrated to deliver $2501 /$ ha of the spray solution at a pressure of $2.5 \mathrm{~kg} / \mathrm{cm}^{2}$.

Watering of the germinated seedlings was carried out at two days interval commencing from the fifth day after sowing till the time the experiment was terminated. No fertilizer application was carried out.

Data collected included plant height, number of leaves per plant, and stem girth. Soil samples were also collected from the pots for microbial analysis at the termination of the experiment.

\subsection{Determination of Pre-Treatment Chemical Properties of Soil}

Soil texture, $\mathrm{pH}$, Organic matter and soil nutrient status of the air dried soil sample were determined following standard methods (AOAC, 1990). The soil samples were analyzed for total $\mathrm{N}$ using Kjeldahl digestion and distillation method. Available phosphorus by the Bray $\mathrm{P} 1$ method, exchangeable $\mathrm{K}, \mathrm{Ca}$ and $\mathrm{Mg}$ were determined by extraction with $1 \mathrm{M}$ ammonium acetate at $\mathrm{pH}$ 7.0. K, $\mathrm{Ca}$ and $\mathrm{Mg}$ contents were determined with flame photometer. Soil $\mathrm{pH}$ (1:2 soil-water) was determined by $\mathrm{pH}$ meter, while organic matter (OM) was determined by dichromate oxidation method.

\subsection{Enumeration of Soil Microbial Population}

Numbers of microflora were estimated using the soil dilution technique on Nutrient and Potato Dextrose Agars as isolation media for bacteria and fungi, respectively. To achieve the serial dilutions, 5 grams of each soil sample was suspended in $150 \mathrm{ml}$ Erlenmeyer flask 
containing $95 \mathrm{ml}$ of sterilized distilled water to obtain a $10^{-1}$ dilution and was agitated on an orbit shaker at $120 \mathrm{rpm}$ for 15 minutes. From the $10^{-1}$ dilution flask, $1 \mathrm{ml}$ of suspension was transferred to $9 \mathrm{ml}$ water blank to make $10^{-2}$ dilution. The water blank was vortexed and then again $1 \mathrm{ml}$ of the suspension was transferred to a new water blank $(9 \mathrm{ml})$ tube to obtain $10^{-3}$ dilution. In similar manner, dilutions were made up to $10^{-8}$. The nutrient agar medium used comprised of $5 \mathrm{~g}$ peptone, $3 \mathrm{~g}$ of meat extract, $15 \mathrm{~g}$ of agar agar and $1000 \mathrm{~mL}$ distilled water. For bacterial count $0.1 \mathrm{ml}$ aliquot of the dilution to $10^{-8}$ was spread plated on Nutrient Agar medium petri plates in triplicates. Then the plates were incubated in an inverted position at $28^{\circ} \mathrm{C}$ for 2 days. The constituents of the Potato Dextrose Agar $\left(\mathrm{gL}^{-1}\right)$ were Peptone 5.0, potato extract 5.0, dextrose 10.0, Agar 20.0, and Distilled water $1000.0 \mathrm{ml}$ at pH 6.5. A mixture of $1 \mathrm{~g}$ soil and $10 \mathrm{~mL}$ of saline solution were shaken on a mechanical shaker for about 10 minutes to dislodge the fungal propagules into the solution. This was followed by serial dilutions to the concentrations of $10^{-5} .0 .5 \mathrm{~mL}$ of the aliquot was spread on Potato dextrose extract agars to isolate fungal spores and this was incubated at $28^{0 \mathrm{C}}$ for 4 days. Dilution factors of 8 and 5 were used to determine the bacterial colony and fungal spore forming units, respectively.

\subsection{Statistical Analysis}

Data collected were subjected to analysis of variance (ANOVA) and means were separated using the Tukey Test at $5 \%$ level of probability $(\mathrm{p}<0.05)$ as outlined by Little and Hills (1978). The bar chart was plotted using Microsoft excel while the correlation and regression analysis, regression curves potted and $\mathrm{R}^{2}$ values determined using the Minitab software (version 17).

\section{Results}

\subsection{Treatment Effects on seed Germination and Seedling Establishment}

Seedling emergence was observed at 5 days after sowing (DAS) in all the pots. Chlorotic symptoms were however noticed in the diuron treated pots regardless of the time of application before sowing (data not shown). Percentage germination was significantly $(\mathrm{P}<$ 0.05) lower in pots treated at 0 and 3 weeks before sowing (WBS) than in the other soils earlier treated with diuron including the control (Figure 1). A good percentage of the plants in the treated pots died back within the first week after emergence, and at the end of the third week after planting (WAP), 100\% mortality was recorded in all diuron treated pots (Figure 1). Percentage Mortality appeared to be inversely related to time of diuron application before sowing $C$. olitorius as observed within the first week after seedling emergence.

\subsection{Treatment Effects on the Growth of C. Olitorius}

Table 1 shows the effects of diuron residues on the growth parameters used to assess $C$. olitorius response to the herbicide before die-back. All the diuron treatments significantly ( $\mathrm{p}$ $<0.05)$ reduced the foregoing growth parameters compared to the control at 2 and 3 weeks after planting (WAP). Among the diuron treatments, a similar trend of influence by the herbicide was noticed on the plant height, number of leaves and stem girth irrespective of the week of sampling after planting. All of these parameters appeared to reduce in value as the week of diuron treatment before planting reduced. At the third week after planting, 


\section{Macrothink

percentage reduction in plant height, number of leaves and stem girth for diuron treatment at 12 WBS were 83, 59 and 38 respectively, whereas these percentages were 92, 71 and 46 respectively for the herbicide treatment at zero week before sowing (0 WBS). Significant differences were not observed among these parameters for diuron treatments at 6,3 and 0 WBS, and means obtained for these parameters as influenced by diuron treatments at 12 and 9 WBS did not also show any statistically detectable significant differences.

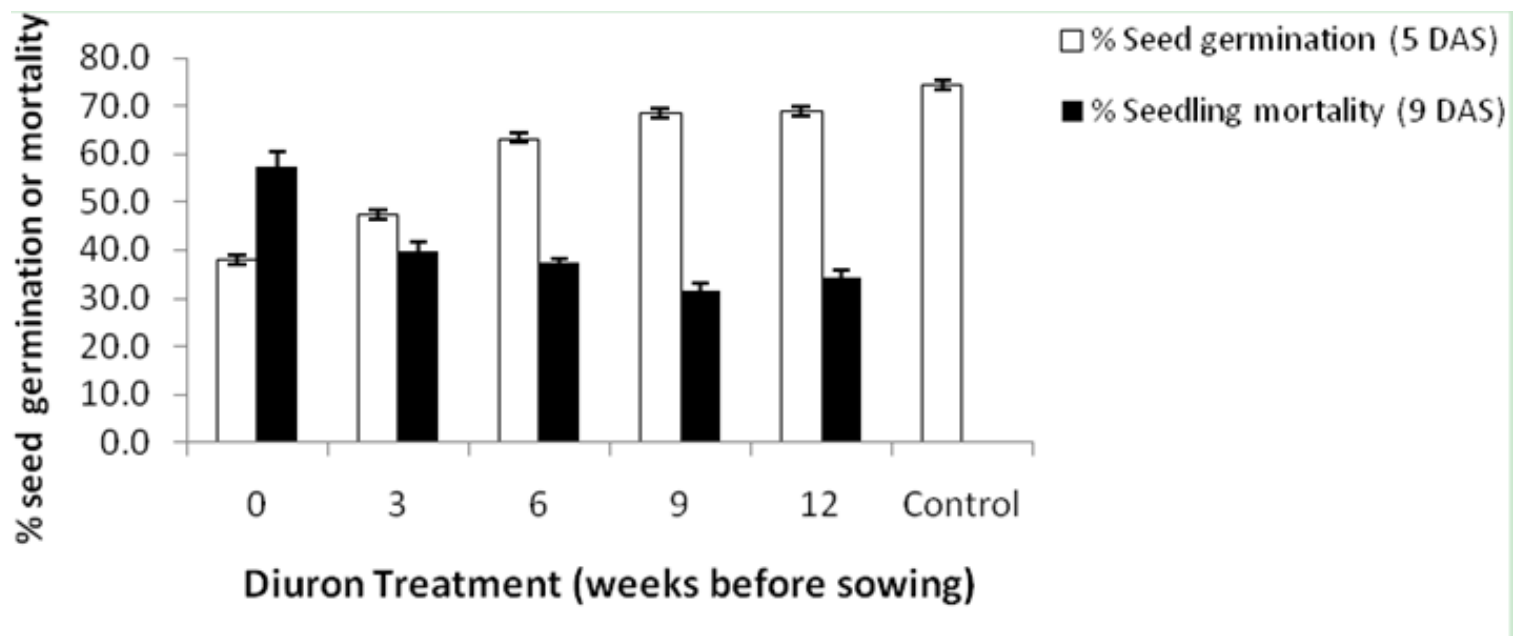

Figure 1. Percentage seed germination and seedling mortality as influenced by diuron treatments

Table 1. Effects of diuron residues on growth parameters of C. olitorius prior to seedling mortality

\begin{tabular}{|c|c|c|c|c|c|c|}
\hline \multirow[b]{3}{*}{ TREATMENT } & \multicolumn{6}{|c|}{ Growth parameters } \\
\hline & \multicolumn{2}{|c|}{ Plant height } & \multicolumn{2}{|c|}{ Number of leaves } & \multicolumn{2}{|c|}{ Stem girth } \\
\hline & 2WAP & $3 \mathrm{WAP}$ & 2WAP & $3 \mathrm{WAP}$ & 2WAP & 3WAP \\
\hline oWBS & $0.65^{\mathrm{c}}$ & $0.85^{\mathrm{d}}$ & $2.00^{c}$ & $2.00^{c}$ & $0.25^{\mathrm{c}}$ & $0.27^{\mathrm{b}}$ \\
\hline $3 \mathrm{WBS}$ & $0.70^{\mathrm{c}}$ & $0.87^{\mathrm{d}}$ & $2.00^{\mathrm{c}}$ & $2.13^{\mathrm{c}}$ & $0.23^{\mathrm{bc}}$ & $0.27^{\mathrm{b}}$ \\
\hline 6WBS & $0.93^{c}$ & $1.31^{\mathrm{cd}}$ & $2.13^{b c}$ & $2.25^{\mathrm{c}}$ & $0.28^{\mathrm{bc}}$ & $0.29^{b}$ \\
\hline 9WBS & $1.31^{\mathrm{b}}$ & $1.48^{\mathrm{bc}}$ & $2.38^{\mathrm{bc}}$ & $2.44^{\mathrm{bc}}$ & $0.30^{\mathrm{b}}$ & $0.29^{\mathrm{b}}$ \\
\hline $12 \mathrm{WBS}$ & $1.43^{\mathrm{b}}$ & $1.86^{\mathrm{b}}$ & $2.50^{\mathrm{b}}$ & $2.88^{\mathrm{b}}$ & $0.30^{\mathrm{b}}$ & $0.31^{\mathrm{b}}$ \\
\hline Control & $6.09^{\mathrm{a}}$ & $11.16^{\mathrm{a}}$ & $5.38^{\mathrm{a}}$ & $7.00^{\mathrm{a}}$ & $0.43^{\mathrm{a}}$ & $0.50^{\mathrm{a}}$ \\
\hline
\end{tabular}

Means in a column carrying same letter(s) are not significantly different from each other.

\subsection{Treatment Effects on Soil Microbial Population}

Table 2 shows the effects of diuron treatments on bacterial and fungal populations of the treated soil determined at the $3^{\text {rd }}$ week after planting. All diuron treatments significantly reduced both bacterial and fungal populations relative to the untreated control. Significant variations also occurred among the different treatments in soil microbial count, but soil bacterial and fungal populations were not affected by the herbicide treatments in any consistent manner in the herbicide treated pots. This variation was more pronounced with the 


\section{Macrothink}

fungal population. Percentage reduction was also not consistent with time before diuron application. Percentage bacterial population reduction were 61.7, 66.8. 69.0, 68.2 and 69.3 in soil treated with diuron at $0,3,6,9$ and 12 WBS respectively, while the treatments reduced fungi by $24.2,25.3,47.4,34.7$ and $68.4 \%$ in that order.

Table 2. Bacteria $\left(\mathrm{X} 10^{7}\right)$ and Fungi $\left(\mathrm{X} 10^{5}\right)$ populations of the soil sample after the experiment

\begin{tabular}{lll}
\hline Treatment & Bacteria (cfu/g soil) & Fungi (sfu/g soil) \\
\hline 0WBS & $2.86^{\mathrm{b}}$ & $7.2^{\mathrm{b}}$ \\
$3 \mathrm{WBS}$ & $2.48^{\mathrm{bc}}$ & $7.1^{\mathrm{a}}$ \\
$6 \mathrm{WBS}$ & $2.31^{\mathrm{bc}}$ & $5.0^{\mathrm{c}}$ \\
$9 \mathrm{WBS}$ & $2.37^{\mathrm{bc}}$ & $6.2^{\mathrm{bc}}$ \\
$12 \mathrm{WBS}$ & $2.29^{\mathrm{c}}$ & $3.0^{\mathrm{d}}$ \\
Control & $7.46^{\mathrm{a}}$ & $9.5^{\mathrm{b}}$ \\
\hline
\end{tabular}

Means in a column carrying same letter(s) are not significantly different from each other.

Correlation analysis between time of diuron application before planting and the growth parameters of $C$. olitorius or microbial count determined at the $3^{\text {rd }}$ week after planting indicated correlation coefficients with P-values (in parenthesis) of 0.95 (0.000), 0.87 (0.000), $0.62(0.014),-0.68(0.006)$ and $-0.82(0.000)$ for plant height, number of leaves, stem girth, bacterial and fungal counts respectively. The regression curves generated from the correlation and regression analysis are shown in figure 2. An increase was observed in the height and leaf numbers of $C$. olitotius while stem girth only mildly responded with respect to the time of diuron application before sowing. Both the bacterial and fungal populations responded negatively to the time of herbicide treatment before sowing but these effects appeared to be more pronounced on the fungal population. 

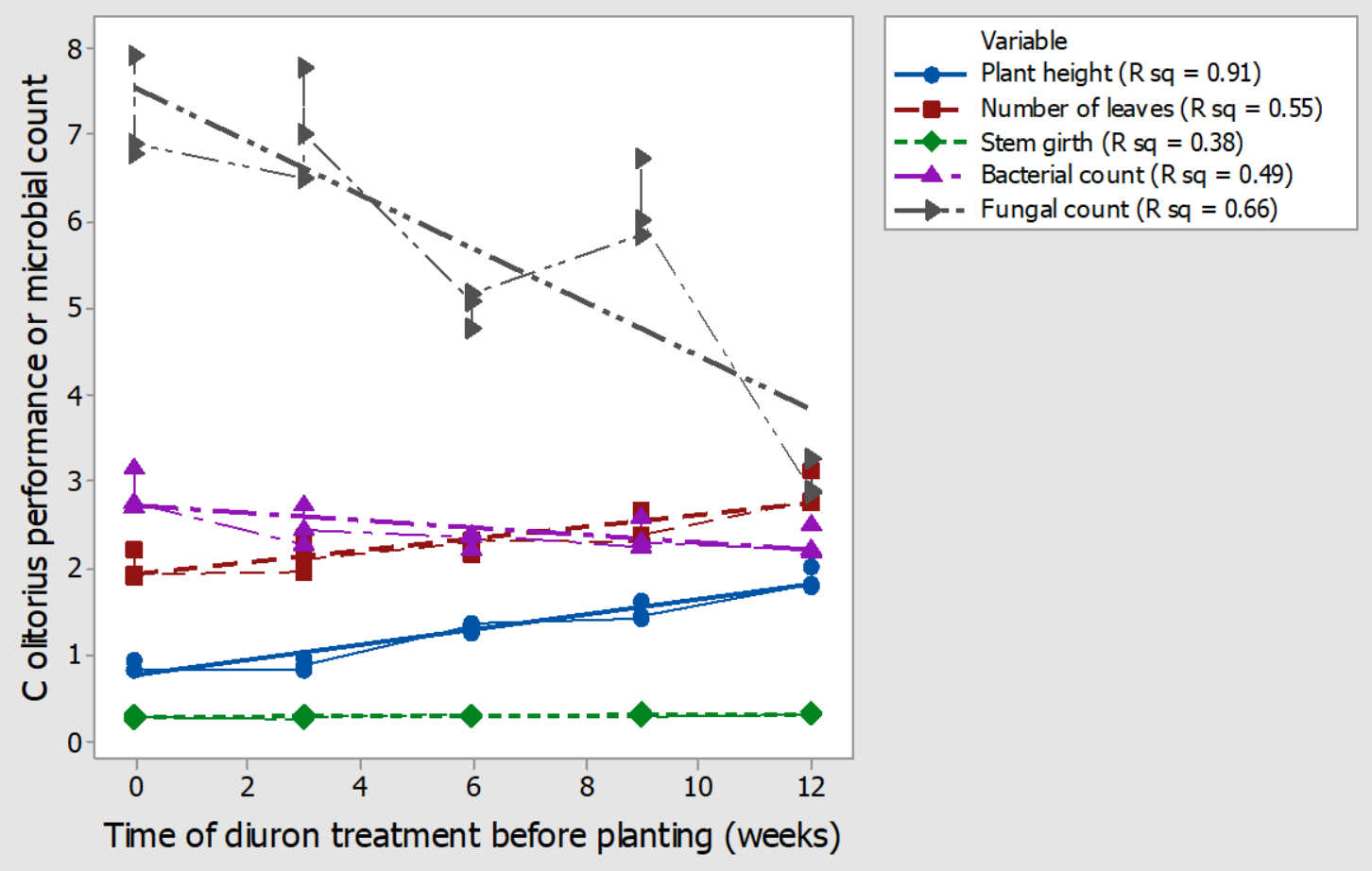

Figure 2. Linear regression curves between time of diuron application before sowing $(X)$ and C. olitorius parameters $(\mathrm{Y})(\mathrm{n}=5)$

\section{Discussions}

Record of seed germination in all the pots irrespective of time of diuron application and the subsequent appearance of chlorotic symptoms observed after seed germination in diuron treated pots confirmed the assertion that diuron allows seeds to germinate normally, but causes them to lose their green color, after which they soon die of starvation (Ferrell et al., 2004). Diuron, a photosynthetic inhibitor functions by inhibiting the Hill reaction in photosynthesis (Hess and Warren, 2002) and as such the herbicide applied pre-emergent is not likely to prevent weed seed germination but may adversely affect plants at leaf development when photosynthesis is expected to commence. The positive relationship that existed between the time of soil treatment with diuron and growth of $C$. olitorius suggested that the phytotoxicity of diuron reduces with time of application before sowing a sensitive rotational crop. This confirms the claim that phytotoxic residues in diuron generally dissipate within a season when applied at low selective rates (Kidd and James, 1991). Crop injury may occur when they are planted within the first 12 months of diuron application (Sheets and Harris, 1995). The record of $100 \%$ mortality in all the treated pots irrespective of the application time indicated that $C$. olitorius plants are susceptible to the phyto-toxic effects of the herbicide, and probably that of the degradation metabolites. It has been reported that the two metabolites of diuron, $\mathrm{N}$ - (3,4-dichlorophenyl)-N-methylurea and $\mathrm{N}-3$, 4-dichlorophenylurea present a three times higher toxicity than that of diuron (Bauer, 1998). Plant mortality could also have resulted from enhanced susceptibility of the plants to root rot disease engendered by diuron. Some plant pathologists (Guo and Ko, 1996) have reported 
that diuron greatly increased incidence of the root rot by increasing susceptibility of anthurium to the disease. The influence of the varying time of herbicide application before planting on the growth parameters of the vegetable followed a pattern that suggested that application at 12 and 9 WBS affected the growth parameters in a similar manner, and differently as from the $6^{\text {th }}$ week before sowing. This pattern can be used to measure diuron dissipation and can therefore, be explained with the fact that phytotoxic residues of diuron generally dissipate within a season when applied at low selective rates, and at higher application rates, residues may even persist for more than one year (Kidd and James, 1991).

Responses of indicator plants to residual herbicides has been classified into the activity categories of stimulation (100\% safe), no response (90-100\% safe), slight damage (70-90\%, slight risk), moderate damage (50-70\%, significant damage) and severe damage (0-50\%, crop failure) (Wibawa et al., 2009). Thus, treatment with diuron at its field recommended rate gave an indicator response showing the treatments caused $100 \%$ seedling mortality (crop failure) even at about 15 weeks after diuron application. Diuron can therefore be classified into causing severe damage as seen in this experiment.

Reduction in soil bacterial and fungal populations irrespective of the time of diuron application to soil also confirmed previous findings that diuron is able to disrupt the complex ecological community of soil microorganisms, including algae and fungi. These effects have been widely reported by soil scientists (Heydrich and Fernández, 1984; Prado and Airoldi, 2001) in a variety of ecosystems. The herbicide has also been found to adversely affect certain nitrogen cycling organisms (Flores and Barbachano, 1992). This observed decrease in the soil microbial population compared to the control treatment can therefore be associated with the toxic effects of diuron on soil microorganisms, which probably did not adapt to the herbicide. Similar results were obtained by Adejoro (2016) when soil samples were treated with cypertmethrin, a synthetic pyrethoid insecticide. The initial reduction of the microbial population was followed by a gradual increase up to the zero week of treatment before planting. This increase in the fungal and bacterial populations could be due to the fact that herbicides or its degraded products and the dead microbial cells killed by the herbicide served as a source of carbon or energy for the surviving microorganisms for cell proliferation (Goswami et al., 2012). Application of herbicides to soils has been reported to inhibit some sensitive species while others rapidly appear to replace the sensitive species subsequently maintaining the metabolic integrity of the soil (Adejoro, 2016). Previous reports on the effect of pesticide application on soil microorganisms have also shown that when pesticides are applied to the soil at sufficient and optimum concentrations, microbes are killed or reduced in numbers. But microbial population increases rapidly to attain a level far in excess of the initial population due to reduction in microbial competition (Adam and Duncan, 2001) and use of cell debris of killed cells by the survivor population (Goswami et al., 2013).

The fluctuations observed especially in the fungal populations relative to changes in the week of herbicide treatment before sowing suggested that the microbial population probably did not only respond to diuron toxicity. The herbicide was expected to dissipate and loose its toxic influence with an extended time of application to the soil. However, lack of consistency in the responses of microbial populations to the herbicide treatment based on the application 
time before sowing as well as the consistent percentage reduction in microbial populations as the WBS reduced, gave an indication that the degradation products of diuron formed with its application time appeared also to be toxic to soil microbes, or that the surviving microbial community was yet to regain competence to metabolize $\mathrm{N}$-(3,4-dichlorophenyl)-N-methylurea and $\mathrm{N}-3,4$-dichlorophenylurea, which remains the metabolites of the parent diuron herbicide.

\section{Conclusions}

The results of this study indicated that pre-emergence application of diuron imposed negative influences both on the sensitive vegetable (test crop) (Corchorus olitorius) and the population of soil bacteria and fungi. Toxicity to fungal population persisted and even increased up to 12 weeks after diuron application to the soil. This is an indication that diuron is a persistent herbicide with residues, which may be toxic to sensitive crops when they are planted too closely in rotation to the main crop in which diuron has been used to control weeds. It is therefore, recommended that a period of fallow be observed after diuron application in crops before using the soil for vegetable production. This period of fallow may also be required to allow the soil fungal communities recover from the toxic effects of the herbicide, as well as to acclimatize with the seemingly more toxic metabolites. It is however, further suggested that this experiment be carried out under field conditions.

The discrepancies observed in the direction of response of the test plant and soil microbial population to the time of diuron application was informative. The strong positive relationships between WBS and the growth parameters measured on the plant suggested $C$. olitorius was more sensitive to the toxic effects of the parent compound (diuron) than those of the metabolites. The inverse relationship exhibited by the fungal population in response to the time of herbicide application on the other hand, indicated that the organisms thrived better when the herbicide was freshly added to the soil.

\section{References}

Adam, G., \& Duncan, H. (2001). Development of a sensitive and rapid method for the measurement of total microbial activity using fluorescein diacetate (FDA) in a range of soils, Soil Biology and Biochemistry, 33, 943-951.

https://doi.org/10.1016/S0038-0717(00)00244-3

Adejoro, S. A. (2016). Interaction Effects of Glyphosate and Cypermethrin on Soil Basal Respiration and Carbon Mineralization Quotient. Applied Tropical Agriculture, 21(1), 7-14.

Aladesanwa, R. D., \& Adejoro, S. A. (2009). Weed control in maize (Zea mays L.) with atrazine and its soil residual activity on the growth and yield of amaranth (Amaranthus cruentus (L.) Sauer) in Southwestern Nigeria. Weed: Management, Economic Impacts and Biology: Nova Science Publishers, Inc. New York. Pp 87-99.

AOAC. (1990). Official Methods of Analysis. 15th edition. Association of Official Analytical Chemists, Washington, DC, USA.

Bauer, E. R. S. (1998). Application of an androgen receptor assay for the characterization of 
the androgenic or antiandrogenic activity of various phenylurea herbicides and their derivatives. Analyst, 123, 2485-2487. https://doi.org/10.1039/a804606i

Ferrell, M. A., Miller, S. D., \& Whitson, T. D. (2004). Basic Guide to Weeds and Herbicides. Department of Plant Sciences, University of Wyoming. [Online] Available: www.uwyo.edu/plants/wyopest/TrainingManuals/Weedctrl.pdf

Flores, M., \& Barbachano, M. (1992). Effects of herbicides Gramoxone, Diuron and Totacol on growth and nodulation of three strains of Rhizobium meliloti. Sci. Tot. Environ. 123/124, 249-260. https://doi.org/10.1016/0048-9697(92)90150-Q

Gadkari, D. (1988). Assessment of the effects of the photosynthesis-inhibiting herbicides Diuron, DCMU, metamitron, and metribuzin on growth and nitrogenase activity of Nostoc muscorum and a new cyanobacterial isolate, strain G4. Biol. Fertil. Soils, 6, 50-54. https://doi.org/10.1007/BF00257920

Goswami, M. R., Pati, U. K., Chowdhury, A., \& Mukhopadhyay, A. (2013). Studies on the effect of cypermethrin on soil microbial biomass and its activity in an alluvial soil. International Journal of Agricultural and Food Science, 3(1), 1-9.

Guo, L. Y., \& Ko, W. H. (1996). Nature of enhanced severity of Anthurium root rot by diuron treatment for weed control. Journal of Phytopathology, 144, 7-11.

https://doi.org/10.1111/j.1439-0434.1996.tb01480.x

Hess, D., \& Warren, F. (2002). The Herbicide Handbook of the Weed Science Society of America $8^{\text {th }}$ Edition. 159-161.

Heydrich, M., \& Fernández, C. (1984). Changes in the composition of the actinomycete community in a soil treated with diuron. In Soil biology and conservation of the biosphere, 1, Ed. J. Szegi. Budapest: Akadémiai Kiadó, 209-215.

Kidd, H., \& James, D. R. (1991). The Agrochemicals Handbook. Royal Society of Chemistry (Eds.). Information Services, Cambridge, UK Weed. Sci., 17(4), 15-20. Little TM, Hills FJ. 1978. Agric experimentation; Design and Analysis John Wiley and Sons Inc. 350.

Pipe, A. E., \& Cullimore, D. R. (1980). An implanted slide technique for examining the effects of the herbicide diuron on soil algae. Bull. Environ. Contam. Toxicol., 24, 306-312. https://doi.org/10.1007/BF01608114

Pipe, A. E., \& Cullimore, D. R. (1984). Influence of five phenylurea herbicides on the diatom Hantzschia in a sandy loam soil. Bull. Environ. Contam. Toxicol., 33, 439-443. https://doi.org/10.1007/BF01625567

Prado, A. G. S., \& Airoldi, C. (2001). The effect of the herbicide diuron on soil microbial activity. Pest. Manag. Sci., 57, 640-644. https://doi.org/10.1002/ps.321

Sheets, T. J., \& Harris, C. I. (1995). Herbicide residues in soils and their phytotoxicity to vegetable crops grown in rotation. Residue Rev., 11, 119-140. 
Tomlin, C. (2000). The Pesticide Mannual, 12th edn, BCPC, Famham Surrey, UK, pp 331-332.

Vieira, R. F. (1999). Microbiological parameters indicators of the effect of diuron on soil microflora, Pesqui Agropec Bras, 34, 897-902.

https://doi.org/10.1590/S0100-204X1999000500024

Welp, G., \& Brummer, G. W. (1999). Effects of organic pollutants on soil microbial activity: the influence of sorption, solubility and speciation. Ecotox Environ Safe, 43, 83-90. https://doi.org/10.1006/eesa.1999.1770

Wibawa, W., Bin Mohamad, R., Bin Puteh, A., Omar, D., Shukor, A., Sheikh, J., \& Abdullah, A. (2009). Residual Phytotoxicity Effects of Paraquat, Glyphosate and Glufosinate-Ammonium Herbicides in Soils from Field-Treated Plots Int. J. Agri. Biol., 11(2), 214-216.

\section{Copyright Disclaimer}

Copyright for this article is retained by the author(s), with first publication rights granted to the journal.

This is an open-access article distributed under the terms and conditions of the Creative Commons Attribution license (http://creativecommons.org/licenses/by/3.0/). 